\title{
MODEL MODUL KONSELING SEBAYA TENTANG KESEHATAN REPRODUKSI REMAJA
}

\section{MODELS OF PEER COUNSELLING MODULES ABOUT ADOLESCENTS REPRODUCTIVE HEALTH}

\author{
Ismiyati $^{1}$, Rangga Walessa ${ }^{2}$, Deni K.Sunjaya ${ }^{3}$, Susi Susanah ${ }^{4}$ \\ ${ }^{1}$ Poltekkes Kemenkes Banten \\ ${ }^{2}$ BKKBN Provinsi Banten \\ ${ }^{3}$ Departemen Ilmu Kesehatan Masyarakat Fakultas Kedokteran Universitas Padjadjaran \\ ${ }^{4}$ Departemen Ilmu Kesehatan Anak Fakultas Kedokteran Universitas Padjadjaran \\ Korespondensi: ismiyati@poltekkesbanten.ac.id
}

\begin{abstract}
Free sexual behavior is a problem of adolescents of concern. Free sex can cause new problems such as teen pregnancy, teenage marriage, teenage childbirth, and sexually transmitted diseases. The Government's effort in overcoming adolescent problems uses a peer approach through PIK $R$ (Youth Information and Counseling Center). However, 50\% of PIK administrators said they lacked confidence in providing counseling to their friends. So that module is needed that suit their needs. This study uses a qualitative method. The number of informants used was 11 people. This research was conducted in January-June 2017 in Banten Province. The counseling module contains counseling and substance needed to be related to adolescent reproductive health. Modules must be able to provide an overview and teach the counseling process, competency counseling, and counseling ethics.
\end{abstract}

Keywords : Adolescent Reproductive Health, Family Planning, Peer Counseling Module

\begin{abstract}
ABSTRAK
Perilaku seks bebas menjadi permasalahan remaja yang menjadi perhatian. Perilaku seks bebas dapat menyebabkan permasalahan baru seperti kehamilan remaja, pernikahan remaja, persalinan remaja, dan penyakit menular seksual. Upaya Pemerintah dalam mengatasi permasalahan remaja menggunakan pendekatan teman sebaya melalui PIK R (Pusat Informasi dan Konseling Remaja). Namun, 50\% pengurus PIK mengatakan kurang percaya diri dalam memberikan konseling pada temannya. Sehingga dibutuhkan modul yang sesuai dengan kebutuhannya. Penelitian ini menggunakan metode kualitatif. Jumlah informan yang digunakan sebanyak 11 orang. Penelitian ini dilakukan pada bulan Januari-Juni 2017 di Provinsi Banten. Modul konseling berisi tentang konseling dan substansi yang dibutuhkan terkait kesehatan reproduksi remaja. Modul harus mampu memberikan gambaran dan mengajarkan Proses konseling, Kompetensi konseling, serta Etika konseling.
\end{abstract}

Kata Kunci : Modul Konseling Sebaya, Keluarga Berencana, Kesehatan Reproduksi Remaja 


\section{PENDAHULUAN}

Permasalahan remaja di Provinsi Banten masih menjadi perhatian. Permasalahan tersebut diantaranya adalah perilaku seks bebas. Perilaku seks bebas tersebut dapat menyebabkan permasalahan baru seperti kehamilan remaja, pernikahan remaja, persalinan remaja, dan penyakit menular seksual. Permasalahan tersebut dapat dipengaruhi oleh faktor lingkungan seperti keluarga, pergaulan, tenaga kesehatan, dan adanya tempat-tempat prostitusi.(Ismiyati et al., 2019)(Kuswandi et al 2019)

Upaya Pemerintah melalui Program Pusat Informasi dan Konseling Remaja/Mahasiswa (PIK R/M) dalam mengatasi permasalahan remaja menggunakan pendekatan teman sebaya. Remaja akan merasa senang, nyaman, dan bebas berbicara dalam mendiskusikan masalah seksual dan kesehatan reproduksi dengan teman-teman sebayanya. (BAPPENAS,2015) Teman sebaya memiliki kedudukan yang sama dalam usia, latar belakang, status sosial, dan tujuan. Teman sebaya memiliki peran penting dalam perkembangan psikososial remaja. Remaja berpendapat bahwa teman sebaya lebih dapat memenuhi kebutuhan dan menerima perbedaan pendapat dari pada orang dewasa. Mairo et al menyatakan bahwa komunikasi teman sebaya merupakan faktor yang paling berhubungan dengan kesehatan reproduksi remaja putri di pondok pesantren. Mereka masih menganggap tabu bila membicarakan kesehatan reproduksi dengan guru (ustad/ustadzah) di pondok pesantren. Hubungan guru dengan murid memiliki jarak karena adab atau sopan santun tersendiri.(Mairo et al, 2015)

Pendidikan dan konseling sebaya sangat efektif digunakan untuk mempromosikan kesehatan remaja. Penerapan pendidikan atau konseling sebaya perlu diimplementasikan secara bersama dengan pendidik atau konselor terlatih, fasilitas kesehatan yang ramah dan menarik, kegiatan yang mendorong remaja untuk memanfaatkan layanan, dan dukungan masyarakat atau lingkungan sekitar. Layanan pendidikan atau konseling seksualitas yang komprehensif juga menjadi faktor pendorong dalam keberhasilan promosi kesehatan remaja.( Mouli, 2015)

Pendidikan dan konseling sebaya pada PIK R/M memfasilitasi remaja supaya lebih nyaman dalam berbagi permasalahan terkait Kesehatan Reproduksi Remaja (KRR) denga teman sebaya. Kegiatan konsultasi, informasi, dan edukasi pada PIK R/M diharapkan dapat menjadikan remaja yang sehat, kreatif, mandiri, dan berakhlaqul karimah dalam rangka terwujudnya 
keluarga yang berkualitas. Pemahaman remaja yang didapat tentang kesehatan reproduksi melalui konseling sebaya menjadikan remaja tegar dalam menghadapi masalah dan mampu mengambil keputusan terbaik bagi dirinya.(Harini R, 2014)

Keberhasilan proses konseling ditentukan oleh keterampilan konselor dalam membangun hubungan interpersonal kepada klien atau konseli. Hubungan tersebut akan membuat konseli merasa nyaman dan mau menyampaikan permasalahannya. Namun hasil penelitian Permatasari menunjukkan bahwa pengetahuan konselor PIK R/M tentang teknik dalam memberikan konseling masih kurang. Proses konseling sebaya yang dilaksanakan kurang memperhatikan hubungan sehingga tidak ada kedekatan antara konselor sebaya dan konseli. Hal tersebut menyebabkan tidak ada kepercayaan pada diri konseli terhadap konselor.(Permatasari D, 2013) Studi yang dilakukan oleh Harini et al menemukan bahwa 50\% pengurus PIK M mengatakan kurang percaya diri dalam memberikan konseling pada temannya, 30\% kurang mendapatkan pengetahuan informasi tentang kesehatan reproduksi, dan $20 \%$ menyatakan bahwa media konseling masih sangat terbatas. (Harini R, 2014) Hal tersebut membuat konselor kurang baik dalam melakukan konseling.

Kemampuan konselor dapat ditingkatkan dengan pelatihan. Konselor sebaya harus dibekali kemampuan dalam membangun komunikasi interpersonal, keterampilan konseling, sikap yang dimiliki seorang konselor, dan pemahaman proses konseling. Hal tersebut mengajarkan mereka menjadi pendengar yang baik, memberikan dorongan, motivasi, dan mendukung keputusan dan perilaku sehat pada konseli. Mereka juga harus mengetahui sumber informasi $(\mathrm{KRR} / \mathrm{KB})$ sehingga dapat merujuk rekan-rekan lain untuk memberikan bantuan yang sesuai.(Abdi F, 2013) Pelatihan konselor sebaya ini dapat meningkatkan pengetahuan, sikap, dan keterampilan pada mahasiswa pengurus PIK R/M dalam melakukan konseling pada teman sebaya.(Harini R, 2014)

Keberhasilan pelatihan ditentukan oleh metode yang tepat sesuai dengan kebutuhan dari peserta. Metode tersebut dikatakan tepat bila terjadi perubahan yang positif terhadap peserta pelatihan. Narasumber yang kompeten, berpengalaman, dan dapat mengemas acara pelatihan menjadi menarik juga menjadi faktor pendukung keberhasilan 
pelatihan.(Harini R, 2014) Hal lainnya yang mempengaruhi pelatihan adalah modul.

Modul digunakan sebagai alat bantu pelatihan berupa materi dan tugas-tugas pelatihan yang dapat meningkatkan hasil belajar. Peserta pelatihan dapat mempelajari modul dalam meningkatkan pemahamannya sesuai dengan materi yang ada. Modul memberikan manfaat dalam meningkatkan kualitas layanan konselor yang dapat mengoptimalkan perkembangan konseli.(Rahmawati AH, 2015)

Tujuan penelitian ini adalah untuk membuat model modul konseling yang dapat digunakan oleh remaja dalam memberikan layanan konseling kepada temannya tentang kesehatan reproduksi.

\section{METODE}

Penelitian ini menggunakan desain kualitatif. Informan dalam penelitian ini adalah pengguna layanan konseling sebaya (konselor dan konseli), tenaga kesehatan (dokter obgyn, dokter anak, dan bidan) yang memberikan layanan kesehatan reproduksi dan keluarga berencana, psikolog yang memberikan layanan konseling remaja, BKKBN, Dinas Kesehatan, dan Pembina Pusat Informasi dan Konseling Mahasiswa. Jumlah informan yang digunakan sebanyak 11 orang. Penelitian ini dilakukan pada bulan Januari-Juni 2017 di Provinsi Banten. Izin penelitian yang digunakan pada penelitian ini berasal dari komisi etik penelitian kesehatan Fakultas Kedokteran Universitas Padjadjaran dengan Nomor Surat Persetujuan Etik: 47/UN6.C1.3.2/KEPK/PN/2017

\section{HASIL DAN PEMBAHASAN}

Dari hasil Wawancara mendalam dan FGD didapatkan bahwa di dalam modul Konseling Sebaya Keluarga Berencana dalam Kesehatan Reproduksi Remaja perlu ditambahkan materi tentang konseling. Pada proses konseling juga membutuhkan keterampilan, sehingga didalam modul pelatihan harus ada skenario kasus yang dapat dipraktikkan oleh peserta. Berikut ini merupakan penjabaran dari hasil penelitian tentang isi modul:

Materi konseling yang ada di dalam modul terdiri dari:

a. Konsep Konseling

Seorang konselor agar dapat memberikan layanan konseling membutuhkan pengetahuan konseling. Konselor sebaya perlu mengetahui tentang konsep konseling terkait tujuan dan prinsip konseling. Konseling merupakan upaya membantu agar konseli memahami permasalahannya. Proses konseling disertai pemberian alternatif pemecahan masalah. Keputusan dalam konseling ditentukan oleh seorang konseli (klien). Konselor tidak dapat 
melakukan paksaan terhadapa pilihannya kepada konseli.

"konseling itu usaha membantu. Kita hannya menyodorkan "Ini loh begini begini begini", dikasih pilihan ada A ada $B$ ada $C$ sehingga sekarang terserah dia (klien) memilih yang mana. Kita tidak boleh memecahkan kamu harus begini...." (R1)

\section{b. Etika}

Proses konseling dilakukan atas kemauan konseli, tetapi dalam melakukan konseling memerlukan persetujuan. Informasi yang didapat dari proses konseling harus dijaga kerahasiaannya. Konselor harus menjaga informasi yang disampaikan konseli dari orang lain. Namun, dalam kondisi tertentu informasi tersebut dapat diceritakan pada pihak tertentu. Kondisi tersebut antara lain konselor yang dilayani oleh team konselor dengan kasus khusus. Konselor juga dapat menceritakan informasi apabila untuk kepentingan hukum. Berdasarkan uraian tersebut didapatkan bahwa proses konseling harus memperhatikan etika seperti aspek kesukarelaan dan aspek kerahasiaan.

"Kita juga sebagai konselor jangan sampai membocorkan rahasia orang tersebut" (R7)

\section{c. Tata Nilai konseling}

Konseli yang dihadapi oleh konselor tidak semuanya memiliki budaya yang sama. Konselor harus tanggap dengan budaya yang dimiliki konseli. Namun, konselor tidak boleh membeda-bedakan perlakuan kepada konseli. Pemahaman budaya dibutuhkan oleh konselor untuk memahami nilai-nilai yang dianut oleh konseli. Beberapa budaya akan merasa diperhatikan apabila rasa empati konselor ditunjukkan dengan memberikan sentuhan pada konseli. Pada budaya tertentu menganggap bahwa sentuhan merupakan hal yang tidak sopan. Begitu juga dengan nada suara pada konselor seperti halnya orang sumatra memiliki nada suara yang tinggi dalam berbicara sedangkan orang jawa memiliki nada suara lembut.

"Upper prep tone ini yang agak susah ya karena typecal orangnya beda-beda apalagi diindonesia banyak banget" (R6)

d. Kompetensi

Kompetensi sangat dibutuhkan bagi mereka yang akan menjadi seorang konselor. Seseorang tidak dapat memberikan layanan konseling apabila tidak memiliki kompetensi konseling. Kompetensi tersebut terdiri dari:

1) Pengetahuan

Koselor harus memiliki pengetahuan tentang materi-materi (substansi) yang dibutuhkan dalam konseling. Konselor yang akan memberikan konseling Keluarga Berencana dalam Kesehatan Reproduksi harus mengetahui misalnya tentang keluarga berencana, kesehatan 
fungsi reproduksi, serta penyakit yang berhubungan dengan reproduksi. Pengetahuan tentang substansi dibutuhkan oleh konselor pada saat memberikan informasi untuk membuat alternatif pemecahan masalah.

“.... konselor perlu mengetahui materimateri yang berkaitan dengan apa yang akan disampaikan, ya KB nya kemudian ya kesehatan reproduksi " (R5)

2) Sikap

Sikap yang dimiliki konselor menjadi salah satu bagian dari kompetensi. Sikap yang baik pada diri konselor akan menunjang keberhasilan konseling.

Konseli akan merasa diterima bila seorang konselor memiliki sikap yang baik. Konseli membutuhkan perhatian untuk dapat memulai pembicaraan tentang masalahnya. Sikap empati dibutuhkan agar mereka merasa dimengerti. Seorang konselor tidak boleh mencela ucapan konseli. Komunikasi terbuka pada diri konselor akan mendorong konseli mengungkapkan perasaannya. Sikap yang baik dibutuhkan untuk membentuk hubungan baik.

“....bisa berempati. Konselor sebaya harus bisa merasakan apa yang dirasakan kliennya" (R7)

Ada sikap-sikap yang perlu dihindari pada saat memberikan layanan konseling. Seorang konselor dalam melakukan konseling tidak boleh menghakimi meskipun konseli bersalah. Sikap mengintrograsi dihindari oleh konselor agar konseli tidak merasa ditekan. Konselor juga tidak dapat menunjukkan sikap acuh tak acuh. Konselor harus tetap membantu meskipun permasalahan yang dihadapi konseli adalah sederhana atau ringan. Dalam memberikan solusi, seorang konselor tidak dapat memaksakan pilihannya. Sikap tersebut merupakan sikap yang buruk dalam melakukan konseling. Sikap buruk tidak akan mendukung keberhasilan konseling. Keputusan yang diambil oleh konseli berdasarkan kehendaknya sendiri.

“Konseling itu bukan do'a, bukan menghakimi, tidak menjastifikasi, kemudian tidak memaksa, bukan introgasi" (R5)

\section{3) Keterampilan}

Seseorang membutuhkan pelatihan untuk menjadi konselor. Pelatihan digunakan untuk melatih keterampilan dalam memberikan konseling. Konseling membutuhkan keterampilan baik verbal maupun non verbal sebagai bentuk komunikasi. Hal tersebut digunakan sebagai dasar untuk menjadi pendengar yang baik sebagai seorang konselor. Dia juga harus bisa memahami dan menyampaikan kembali apa yang didengar dari konseli. Keterampilan non verbal konselor ditunjukkan diantaranya 
dengan sikap tubuh yang baik maupun tersenyum dengan penuh perhatian. Selain menunjukkan komunikasi verbal dan non verbal, seorang konselor juga harus bisa mengobservasi konseli dari ekspresi maupun ucapannya.

"Melakukan observasi melihat verbal non verbal diantaranya seperti itu" (R9)

Keterampilan yang dibutuhkan dalam melakukan konseling berupa keterampilan memberi arahan, mendengar aktif, merefleksi, memberikan informasi, memberikan dukungan, dan keterampilan meringkas. Keterampilan memberi arahan dibutuhkan untuk menggali permasalahan konseli dengan pertanyaan tertutup maupun terbuka. Setelah permasalahan konseli diketahui, maka seorang konselor juga perlu memiliki keterampilan memberikan informasi alternatif pilihan dengan komunikasi yang efektif sehingga konseli mampu mengambil keputusan dengan tepat.

"Menggali dulu sebenarnya apa yang dihadapi, dengarkan dengan seksama masalahnya apa sehingga nanti konselor itu bisa memberikan informasi yang tepat dan dukungan, serta diakhir meringkas" (R7)

\section{e. Proses}

Proses konseling dilakukan dengan tahapan sebagai berikut:

1) Tahap Persiapan
Proses konseling dimulai dengan tahapan persiapan. Persiapan yang dibutuhkan diantaranya adalah tempat. Konseling bisa dilakukan dimana saja asalkan tempatnya memenuhi syarat. Tempat dipersiapkan untuk memberikan kenyamanan pada saat konseling. Ruang konseling harus dalam keadaan tenang tanpa ada gangguan dari sekitarnya.

“....tempat yang pasti memenuhi kriteria. Artinya tidak terlalu bising, tidak banyak gangguan, tempatnya mau seperti apa, misalkan di tempat makan ya silahkan" (R5)

Ruangan perlu dipersiapkan tata letaknya agar aman dan kondusif. Benda-benda yang dapat membahayakan tidak boleh didekatkan dengan tempat konseling. Emosi konseli suatu saat dapat memuncak dan tidak dapat dikendalikan sehingga bisa saja melukai dirinya dengan bendabenda disekitarnya. Kondisi tersebut perlu diantisipasi sehingga aksesoris ruangan yang digunakan terbuat dari bahan yang aman. Letak kursipun diposisikan menyamping agar konseli merasa nyaman.

"vas bunga di ruangan jangan yang kaca, jangan juga ada karter di dekat konseli karena siapa tahu dia emosinya ga terkendali terus bunuh diri disitu kan berabe...." (R5)

Selain persiapan tempat, penampilan seorang konselorpun juga perlu 
dipersiapkan. Penampilan konselor menunjukkan kesiapannya dalam memberikan layanan konseling. Konselor memiliki panampilan yang rapi. Konselor juga mampu menunjukkan wajah yang ceria dengan penuh perhatian.

"konselornya rapih, ga boleh manyun...." (R3-FGD)

Media perlu dipersiapkan sebelum memberikan pelayanan konseling sebaya.

Media digunakan sebagai alat bantu untuk mempermudah dalam menyampaikan informasi. Alat bantu yang digunakan untuk konseling sebaya tentang keluarga berencana dalam kesehatan reproduksi remaja dapat berupa lembar balik serta celemek. Celemek dapat berupa gambargambar alat reproduksi. Celemek dipakai oleh seseorang sehingga akan terlihat organ-organ reproduksi yang ada ditubuh manusia.

“....bisa pakai celemek untuk kesehatan alat reproduksi, yang dipakai terus nanti akan nampak bagian-bagiannya" (R9)

Pemberian informasi tentang kontrasepsi selain menggunakan media bergambar juga dapat menggunakan model sesuai jenis kontrasepsi. Model kontasepsi pada salah satu jenis kontrasepsi dapat dipraktikkan tentang cara penggunaannya yang tepat. Model ini adalah pemakaian kondom.
"Pakai kit model KB juga bisa...." (R11)

Pemberian informasi dalam konseling juga dapat menggunakan video dengan bahasa yang mudah dipahami dan hanya digunakan untuk memberikan layanan konseling. Video ini memiliki manfaat agar mudah dipahami bila informasi yang diberikan berupa perilaku atau tindakan sehingga tidak terjadi kesalahan penerimaan pada klien atau konseli. Media informasi berupa video tersebut juga dapat dipasang pada aplikasi sesuai era sekarang yang digunakan pada layanan konseling.

"Gunakan video yang enak dengan omong datar tanpa tedeng aling aling tentang penggunaan kondom. Kalau ditaruh dipisang nanti dibelilah pisang sama dia saat koitus dipake kan di pisang ntar tetep bisa hamil"'(R6)

2) Tahap pembukaan

Tahap pembukaan merupakan bagian terpenting dalam melakukan konseling. Konseli datang melakukan layanan konseling pada orang yang mungkin asing baginya. Konseli mungkin saja merasa tidak nyaman untuk menceritakan permasalahannya. Kondisi tersebut membutuhkan hubungan baik antara konselor dan konseli. Membangun hubungan baik tersebut dimulai dengan memberikan salam, memperkenalkan diri, 
maupun kontrak waktu. Konselor mampu menampilkan tingkah laku verbal dan non verbal yang baik. Membangun hubungan baik ini dibutuhkan untuk menanamkan kepercayaan sehingga konseli mau terbuka dengan permasalahannya.

"didalam konseling perlu membangun good reportt, karena itu penting seperti kita memperkernalkan diri kalau memang belum kenal" (R5)

3) Tahap isi

Keterampilan konseling banyak dibutuhkan pada tahap isi. Pada tahap ini konselor sebaya mampu mengkaji masalah yang dihadapi konseli. Keterampilan bertanya secara terbuka dan mendalam digunakan untuk mengklarifikasi masalah konseli. Namun, pertanyaan diajukan dengan tidak mengintrogasi. Informasi diberikan setelah konselor mengetahui permasalahan konseli. Informasi merupakan alternatif pemecahan masalah agar konseli mampu mengambil keputusan dengan tepat. Informasi diberikan secara lengkap dengan menyebutkan sisi positif dan negatifnya sehingga konseli dapat memahami pilihannya. Pengambilan keputusan perlu mempertimbangkan kondisi konseli, kemungkinan pilihan, konsekuensi pilihan, dan keputusan terbaik.

“...ungkap masalahnya terus
memberikan informasi yang sejelas-
jelasnya agar konseli dapat
mengambil keputusan.” (R7)

4) Tahap penutup

Tahap akhir dari proses konseling akan memastikan tindak lanjut dari hasil konseling dan menawarkan janji pertemuan berikutnya. Pada tahap ini konseli mampu menyimpulkan hasil konseling. Konselor juga mampu menilai keberhasilannya dalam membantu konseli memecahkan masalah.

“.... tawarkan janji untuk bertemu kembali” (R5)

\section{f. Hambatan konseling}

Pengalaman yang dilakukan oleh konselor sebaya pada saat memberikan konseling terkadang menemui masa-masa sulit dalam menghadapi klien seperti konseli diam maupun konseli yang tidak fokus menceritakan permasalahannya. Kondisi tersebut dapat menjadi hambatan dalam melakukan konseling. Hambatan membuat proses konseling tidak berhasil. Hal lain yang dapat menjadi hambatan adalah bahasa dan kondisi klien atau konseli. Bahasa yang digunakan harus dapat dimengerti oleh konselor dan konseli. Konseli juga dalam kondisi fisik dan psikologis yang baik sehingga informasi yang diberikan dapat 
dipahami dengan begitu konseli dapat menentukan pilihan terbaik untuk dirinya.

“...dari bahasa kemudian juga harus paham psikologis dia dalam keadaan tenang atau tidak. Jangan sampai kita memberikan informasi tapi orangnya lagi ga fokus" (RI-FGD)

Isi modul juga harus berisi tentang substansi yang sesuai dengan kebutuhan remaja. Hasil studi ismiyati dkk menyatakan bahwa substansi yang dibutuhkan dalam modul konseling diantaranya tumbuh kembang remaja, kesehatan reproduksi, penyakit seksual, keluarga berencana, napza, gender, mitos, keterampilan hidup (Lifa Skill), advokasi dan KIE (Komunikasi Informasi dan Edukasi), serta pendekatan agama dalam kesehatan reproduksi.(Ismiyati, et all, 2018)(Ismiyati, et all, 2019)

Berdasarkan hasil penelitian maka model modul konseling sebaya keluarga berencana dalam kesehatan reproduksi remaja didapatkan sebagai berikut:

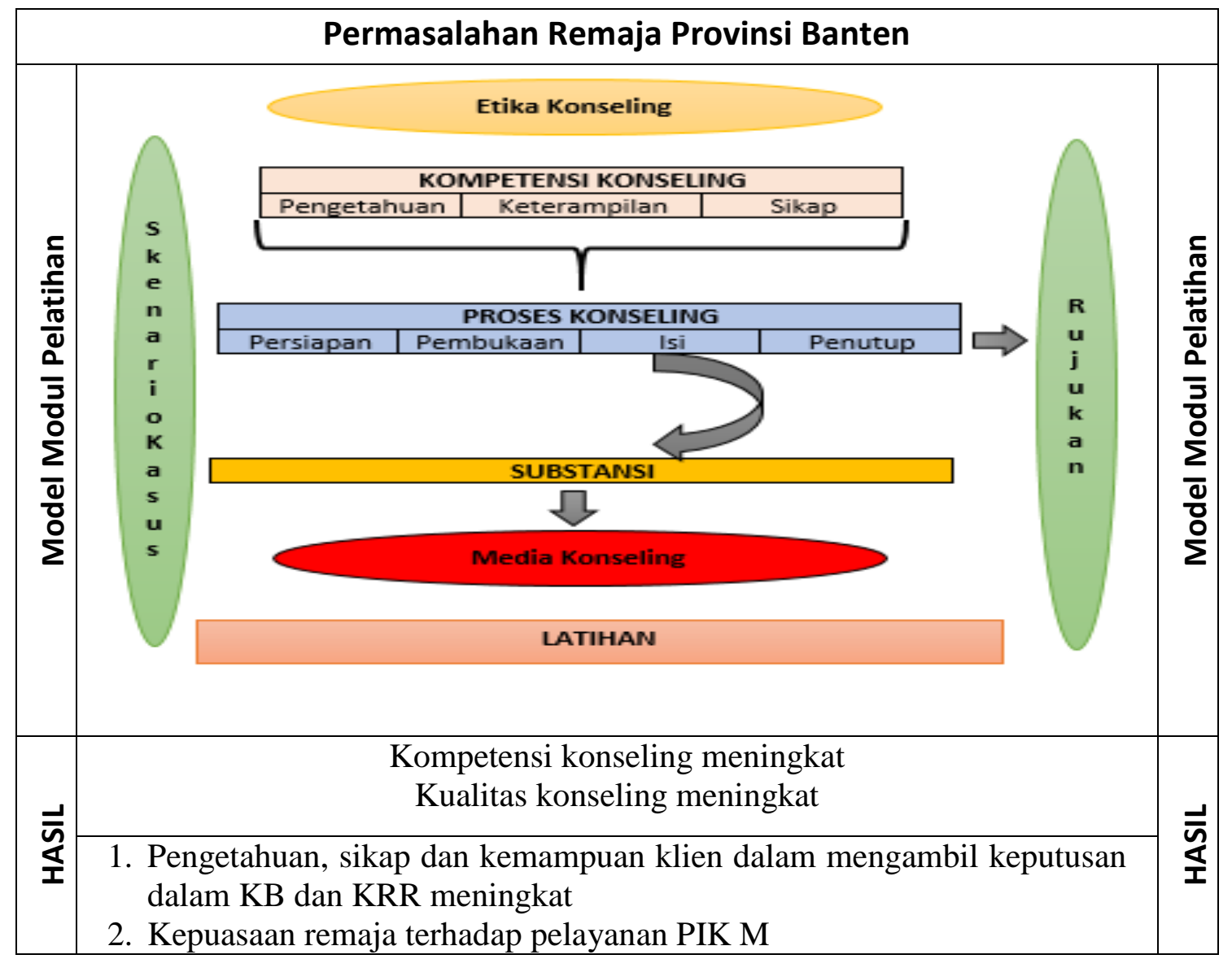

Gambar 1 Model Modul Konseling Sebaya Keluarga Berencana dalam Kesehatan Reproduksi Remaja

Gambar 1 memaparkan suatu model dari modul konseling sebaya keluarga berencana dalam kesehatan reproduksi remaja. Pada model menunjukkan bahwa modul konseling sebaya keluarga berencana dalam kesehatan 
reproduksi remaja mengajarkan peserta latih untuk memiliki kompetensi konseling agar dapat melakukan proses konseling. Tahap isi pada proses konseling terdapat pemberian informasi sehingga dibutuhkan substansi yang sesuai. Pemberian informasi dapat menggunakan media konseling untuk mendukung keberhasilan layanan konseling. Namun, pada penelitian ini untuk media konseling belum dikembangkan. Pada modul ini juga disertakan tentang tempat rujukan, sehingga ketika konselor menemukan masalah yang tidak dapat diselesaikan pada tahap penutup mereka akan melakukan rujukan. Untuk dapat menggambarkan proses konseling secara keseluruhan maka pada modul ini disertakan tentang skenario kasus. Pada akhir modul disertakan tentang latihan untuk mengukur keberhasilan dari proses pelatihan.

Hasil penelitian menunjukkan bahwa didalam modul konseling keluarga berencana dalam kesehatan reproduksi remaja terdiri dari materi konseling, substansi, dan skenario kasus. Materi konseling terdiri dari konsep konseling, etika konseling, tata nilai konselor, kompetensi, proses konseling, dan hambatan konseling. Substansi yang dimasukkan di dalam modul berkaitan dengan keluarga berencan dan kesehatan reproduksi. Sedangkan skenario kasus berisi tentang kasus-kasus yang dijadikan latihan praktik konseling.

Konseling diantaranya mengajarkan bahwa dalam melakukan konseling terdapat upaya membantu pemecahan masalah yang diambil berdasarkan keputusan konseli dengan memperhatikan etika seperti kerahasiaan dan kesukarelaan, serta tata nilai konselor terhadap budaya sekitar. Hal tersebut sesuai dengan konsep bahwa konseling adalah serangkaian kontak langsung dengan individu yang bertujuan untuk memberi bantuan dalam mengubah sikap dan perilaku.(Sharma R, 2016) Mereka bertemu ditempat tertentu pada waktu yang telah disepakati, dalam kondisi kerahasiaan yang terjaga, dan dengan tujuan yang spesifik.( Palmer S, 2011)

Konselor harus memiliki kompetensi dalam melakukan konseling. Dia memiliki pengetahuan tentang substansi yang dibutuhkan dalam konseling. Konselor juga harus memiliki sikap yang baik seperti empati, terbuka, perhatian. Seorang konselor tidak boleh memiliki sikap seperti menghakimi, mengintrogasi, memaksakan kehendak dalam memberikan solusi, maupun sikap yang menunjukkan bahwa konselor tidak butuh atau acuh. Sikap yang ditunjukkan oleh seorang konselor akan menentukan berhasil atau tidaknya proses konseling. Hal ini perlu menjadi suatu 
perhatian karena untuk membangun hubungan saling percaya antara konselor dan konseli. Konselor harus menunjukkan empati, sikap menghormati, penuh perhatian, peka terhadap kebutuhan konseli, dan dapat dipercaya.( Dinç L, 2013)

Kompetensi yang berkaitan dengan keterampilan dalam konseling sangat dibutuhkan baik verbal maupun non verbal sebagai bentuk komunikasi. Konselor memiliki keterampilan bertanya, mendengar aktif, memparafrasekan pikiran konseli, serta merefleksikan perasaan konseli. Pada saat melakukan konseling, seorang konselor harus menggunakan teknik komunikasi. Kemampuan untuk mendengarkan, menafsirkan, dan menanggapi bahasa nonverbal pada konseli adalah keterampilan penting yang dibutuhkan oleh konselor. Keterampilan mendengarkan diperlukan untuk menunjukkan bahwa konselor memahami dan menafsirkan informasi yang disampaikan oleh konseli dengan benar. Komunikasi yang efektif dapat mendorong konseli untuk terus berbicara, terbuka dengan permasalahannya, dan membantu konselor mengeksplorasi masalah secara mendalam.( Sharma R, 2016)

Proses konseling mencakup tahap persiapan, pembukaan, isi, dan penutup. Tahap persiapan dari hasil penelitian ini terdiri dari persiapan dari diri konselor dan tempat untuk menciptakan kenyamanan konseli. Tahap pembukaan digunakan untuk membentuk hubungan baik antara konselor dan konseli yang dibutuhkan untuk menanamkan kepercayaan. Hubungan yang mendukung dan memberdayakan konseli akan mempengaruhi pengalaman positif dalam pemberian intervensi. Hasil Studi penelitian menunjukkan bahwa kualitas hubungan konseli dan konselor akan memberikan kepuasan pada konseli. Sebaliknya, mereka akan merasa kecewa pada konselor yang kurang peduli dengan masalah yang dihadapinya.( Palmadottir G, 2006) Tahap isi merupakan tahap memberikan informasi sebagai alternatif pilihan agar konseli mampu mengambil keputusan dengan tepat. Akhir-akhir ini telah terjadi peningkatan minat klien dalam konsep pengambilan keputusan bersama. Model ini semakin dianjurkan untuk melibatkan konseli dalam proses menentukan atau sebagai tindak lanjut terhadap pilihan yang lebih dari satu.( Elwyn G, 2014) Adanya proses pengambilan keputusan bersama (Share Decision Making) antara konselor dan konseli akan menghasilkan keputusan berdasarkan pemahaman tentang manfaat dan bahaya atau kerugian semua pilihan dan keinginan konseli.( Giguere AMC, 2014) Pada tahap penutup proses konseling akan dipastikan tindak lanjut dari hasil konseling. Konseli akan diminta menyimpulkan hasil 
proses konseling, mengevaluasi, dan membuat perjanjian pertemuan berikutnya. Keberlanjutan pertemuan dibutuhkan untuk mengetahui tindak lanjut kebutuhan konseli sehingga mereka akan memahami bahwa konselor ada untuk mereka.( Eriksson I, 2008)

Konseling tidak dapat berhasil karena adanya hambatan baik dari segi bahasa, kondisi fisik maupun psikis konseli sehingga informasi yang diberikan tidak dapat dipahami. Selain itu, saat-saat konseling juga menjadi kendala dalam melakukan konseling sehingga dibutuhkan teknik untuk mengatasinya.

\section{SIMPULAN}

Hasil penelitian menunjukkan bahwa modul konseling sebaya keluarga berencana dalam kesehatan reproduksi remaja mengajarkan tentang konseling dan substansi yang dibutuhkan terkait kesehatan reproduksi remaja. Modul harus mampu memberikan gambaran dan mengajarkan Proses konseling, Kompetensi konseling, serta Etika konseling.

\section{DAFTAR RUJUKAN}

Abdi F, Simbar M. The peer education approach in adolescents: narrative review article. Iranian J Publ Health. 2013; 42 (11): 1200-6

BAPPENAS. (2015) Laporan pencapaian tujuan pembangunan Milenium di Indonesai 2014. Jakarta.
Cleland J, Agudelo AC, Peterson H, Ross J, Tsui A. (2012) Contraception and health. Lancet; 380: 149-56

Dinç L, Gastmans C. Trust in nurse-patient relationships: a literature review. Nursing Ethics. 2013; 20(5): 501-16

Elwyn G, Dehlendorf C, Epstein RM, Marrin K, White J, Frosch DL. Shared decision making and motivational interviewing: achieving patient-centered care across the spectrum of health care problems. Ann Fam Med. 2014; 12 (3): 270-5

Eriksson I, Nilsson K. Preconditions needed for establishing a trusting relationship during health counselling-an interview study. Journal of Clinical Nursing. 2008; 17: 2352-9

Giguere AMC, Labrecque M, Haynes RB, Grad R, Pluye P, Legare F, et.al. Evidence summaries (decision boxes) to prepare clinicians for shared decisionmaking with patients: a mixed methods implementation study. Implementation Science. 2014; 9 (144): 1-13

Harini R, Rahmat I, Nisman WA. Upaya peningkatan keterampilan konseling kesehatan reproduksi mahasiswa melalui pelatihan konselor sebaya. Jurnal Ners. 2014; 9 (2): 173-82

Ismiyati, Deni, K. S. and Susanah, S. (2018) 'Substansi Modul Konseling Sebaya Dalam Mengatasi Permasalahan Kesehatan Reproduksi Pada Remaja Akhir', Jurnal Medikes, 5 (April), pp. 19.

Ismiyati, I. et al. (2019) 'Reproductive Health Problems in Adolescents in Banten Province Permasalahan Kesehatan Reproduksi pada Remaja di Provinsi Banten', GMHC. 7(12), pp. 5258. Available at: https://ejournal.unisba.ac.id/index.php/g mhc/article/view/3060/pdf.

Ismiyati, Sunjaya, D. K. and Susanah, S. (2019). Kebutuhan substansi modul konseling sebaya tentang keluarga berencana dalam kesehatan reproduksi 
pada remaja. Jurnal Kesehatan Poltekkes Palembang, 14(1), pp. 26543427.

Kuswandi, K., Ismiyati and Rumiatun, D. (2019). Analisis Kualitatif Perilaku Seks Bebas Pada Remaja Di Kabupaten Lebak. Jurnal Kesehatan Poltekkes Palembang, 14(1), pp. 18-24.

Mairo QKN, Rahayuningsih SE, Purwara BH. (2015) Kesehatan reproduksi remaja putri di pondok pesantren sidoarjo jawa timur. MKB; 47 (2): 77-83

Mouli VC, Lane C, Wong S. What does not work in adolescent sexual and reproductive health: a review of evidence on interventions commonly accepted as best practices . Global Health: Science and Practice. 2015; 3 (3): 333-40

Palmadottir G.(2006) Client-therapist relationships: experiences of occupational therapy clients in rehabilitation. British Journal of Occupational Therapy. 69(9): 394-401

Permatasari D. (2013) Faktor-faktor yang mempengaruhi perilaku konselor sebaya dalam implementasi konseling kesehatan reproduksi remaja di Kabupaten Sumenep. Jurnal wiraraja medika. 3 (2): 82-7

Rahmawati AH.(2015) Peningkatan keterampilan konseling konselor sebaya pusat informasi dan konseling remaja MAN Yogyakarta 1. E-Journal Bimbingan dan Konseling UNY. Edisi 4: $1-12$

Sharma R, Dapkekar A, Londhe SN, Ojha P.(February 2016) Prossiding 7th international conferance \& workshop: effecctive communication and counselling skills. Thakur College of Engineering \& Technology. Hlm 138140

Palmer S.(2011) Konseling dan psikoterapi. Pustaka Pelajar Yogyakarta. Hlm 8-9

1. 